\title{
Effect of processing methods and protein content of the concentrate on the properties of milk protein concentrate with $80 \%$ protein
}

\author{
L. S. Rupp, ${ }^{*}$ M. S. Molitor, $†$ and J. A. Lucey ${ }^{*}{ }^{1}$ \\ *Department of Food Science, and \\ †Center for Dairy Research, University of Wisconsin-Madison, 1605 Linden Drive, Madison 53706
}

\begin{abstract}
In recent years, a large increase in the production of milk protein concentrates (MPC) has occurred. However, compared with other types of milk powders, few studies exist on the effect of key processing parameters on powder properties. In particular, it is important to understand if key processing parameters contribute to the poor solubility observed during storage of high-protein MPC powders. Ultrafiltration (UF) and diafiltration (DF) are processing steps needed to reduce the lactose content of concentrates in the preparation of MPC with a protein content of $80 \%$ (MPC80). Evaporation is sometimes used to increase the TS content of concentrates before spray drying, and some indications exist that inclusion of this processing step may affect protein properties. In this study, MPC80 powders were manufactured by 2 types of concentration methods: membrane filtration with and without the inclusion of an evaporation step. Different concentration methods could affect the mineral content of MPC powders, as soluble salts can permeate the UF membrane, whereas no mineral loss occurs during evaporation, although a shift in calcium equilibrium toward insoluble forms may occur at high protein concentration levels. It is more desirable from an energy efficiency perspective to use higher total solids in concentrates before drying, but concerns exist about whether a higher protein content would negatively affect powder functionality. Thus, MPC80 powders were also manufactured from concentrates that had 3 different final protein concentrations (19, 21, and 23\%; made from 1 UF retentate using batch recirculation evaporation, a similar concentration method). After manufacture, powders were stored for $6 \mathrm{mo}$ at $30^{\circ} \mathrm{C}$ to help understand changes in MPC80 properties that might occur during shelf-life. Solubility and foaming properties were determined at various time points during high-temperature powder
\end{abstract}

Received January 3, 2018.

Accepted May 5, 2018.

${ }^{1}$ Corresponding author: jlucey@cdr.wisc.edu storage. Inclusion of an evaporation step, as a concentration method, resulted in MPC80 that had higher ash, total calcium, and bound calcium (of rehydrated powder) contents compared to concentration with only membrane filtration. Concentration method did not significantly affect the bulk (tapped) density, solubility, or foaming properties of the MPC powders. Powder produced from concentrate with $23 \%$ protein content exhibited a higher bulk density and powder particle size than powder produced from concentrate that had $19 \%$ protein. The solubility of MPC80 powder was not influenced by the protein content of the concentrate. The solubility of all powders significantly decreased during storage at $30^{\circ} \mathrm{C}$. Higher protein concentrations in concentrates resulted in rehydrated powders that had higher viscosities (even when tested at a constant protein concentration). The protein content of the concentrate did not significantly affect foaming properties. Significant changes in the mineral content are used commercially to improve MPC80 solubility. However, although the concentration method did produce a small change in the total calcium content of experimental MPC80 samples, this modification was not sufficiently large enough $(<7 \%)$ to influence powder solubility. Key words: milk protein concentrate, solubility, protein functionality, foaming

\section{INTRODUCTION}

Milk protein concentrates (MPC) have become popular dairy ingredients due to their nutritional quality and functionality (Agarwal et al., 2015). The rehydration of high-protein milk powders can be challenging (Singh, 2007; Baldwin, 2010; Richard et al., 2013; Crowley et al., 2015; Vos et al., 2016). Another issue is the deterioration in the solubility of high-protein $(\geq 70 \%)$ powders, such as MPC, during storage, especially when storage is at temperatures $>20^{\circ} \mathrm{C}$ (Anema et al., 2006; Havea, 2006; Mimouni et al., 2010a; Haque et al., 2011). Incomplete rehydration can impair important functional properties and limit the usage of high-protein powder in industrial and consumer applications. Rehydration properties of milk powders are influenced by the con- 
ditions used (solvent temperature, stirring rate), but also by the powder processing methods (Walstra et al., 2006). Several explanations have been proposed to explain the poor rehydration or solubility of MPC. Poor rehydration behavior has been associated with the low concentrations of lactose in high-protein MPC. Lactose molecules have been considered as a spacer material in powder particles, which keeps the proteins separated from each other and hinders protein interactions (Anema et al., 2006). Lactose is also thought to be a contributor to improved water penetration into the inside of a powder particle through a pore-like structural mechanism (Baldwin, 2010; Richard et al., 2013). However, the low lactose content of high-protein MPC cannot explain the significant deterioration in solubility observed during high-temperature powder storage. Another suggestion is increased cross-linking of casein micelles on the surface of the powder particles during storage, although the exact type of cross-linking is still unclear (Anema et al., 2006; Havea, 2006; Gaiani et al., 2007; Mimouni et al., 2010a; Haque et al., 2011). Lipids and proteins are thought to migrate from the core of the powder particle to the surface of the particle during storage, which might increase the hydrophobic interactions on the surface (Gaiani et al., 2009, 2010; Fyfe et al., 2011). It is thought that a crust is formed by the fusion of casein micelles on the surface of the powder particles, which becomes more insoluble or at least slower to disperse (Fyfe et al., 2011).

In recent years, several studies have examined the effect of various processes on MPC functionality, including sonication, ultrasound, and hydrodynamic cavitation (Augustin et al., 2012; Sun et al., 2014; Li et al., 2018), addition of calcium chelating agents (McCarthy et al., 2017), and spray drying conditions (DeCastro and Harper, 2003; Augustin et al., 2012: Fang et al., 2012; Park et al., 2016). The production process for MPC with $80 \%$ protein content (MPC80) involves UF and diafiltration (DF) to reduce the lactose content before spray drying of the concentrates. Evaporation is sometimes used to further increase the TS content of concentrates before drying (Mistry and Hassan, 1991; Singh, 2007). Spray drying requires more energy to remove water than processes such as evaporation or membrane filtration (Walstra et al., 2006). Thus, to reduce energy costs, powder manufacturers would prefer to use concentrates with high TS content. Concentrates with higher protein content would increase their viscosity (Patel et al., 2009) and could alter some functional properties such as solubility. The effect of varying the protein content of concentrates on the solubility and functionality of MPC 80 powders is not well described. Augustin et al. (2012) altered the protein content of concentrates by using different concentration processes and noticed differences in the solubility of MPC. However, because of differences in production methods as well as final protein contents in these MPC powder samples, it was not clear if the solubility issues were caused by differences in protein content of the concentrate.

During the production of MPC80, the extensive UF and DF required depletes soluble minerals and lactose as these components permeate the UF membrane (Singh, 2007). It has been suggested that extensive DF could disrupt casein micelles, possibly due to loss of some colloidal calcium phosphate (CCP; Singh, 2007; Ferrer et al., 2011). It has also been suggested that the addition of an evaporation step after extensive UF/ DF helps reassociate micelles due to increased ionic strength (Singh, 2007). If sufficient loss of stabilizing CCP from the casein micelles occurs, casein dissociation could occur from the micellar structure (Mimouni et al., 2010a).

One objective of our study was to compare different concentration methods on MPC properties for powders that were adjusted to have similar lactose-to-protein ratios. Another objective of our work was to produce MPC80 from concentrates that had different protein concentrations and then investigate various characteristics including solubility and functionality during powder storage at $30^{\circ} \mathrm{C}$ for $6 \mathrm{mo}$.

\section{MATERIALS AND METHODS}

\section{Experimental Setup}

Raw milk ( $\sim 910 \mathrm{~kg})$ was warmed to $32^{\circ} \mathrm{C}$, skimmed, and pasteurized $\left(73^{\circ} \mathrm{C}\right.$ for $\left.19 \mathrm{~s}\right)$ in the University of Wisconsin-Madison Babcock Hall dairy plant. The pasteurized skim milk was processed into 5 unique batches of MPC80 in the Center for Dairy Research pilot plant. Each processing condition was performed in duplicate, and $\sim 5 \mathrm{~kg}$ of each powder containing $\sim 80 \%$ protein were collected. During processing, the TS of the liquids were measured with a refractometer (Master-20M, Atago USA Inc., Bellevue, WA). Immediately after production, the MPC powders were stored at $30^{\circ} \mathrm{C}$ for $6 \mathrm{mo}$ in airtight $50-\mathrm{mL}$ tubes in an incubator and analyzed every $30 \mathrm{~d}$ for compositional and functional properties.

\section{Manufacture of MPC with Different Protein Concentrations in the Concentrate}

Pasteurized skim milk was concentrated to $20 \%$ TS (16 $\pm 1 \%$ protein) using an UF/DF system consisting of 6 elements, each $10.92 \mathrm{~cm}$ in diameter and 96.52 $\mathrm{cm}$ long, with a feed spacer of $2.03 \mathrm{~mm}$ (model MK5B-4338-PHT, $30 \mathrm{kDa}$ molecular weight cutoff, Synder 
Filtration, Vacaville, CA). Ultrafiltration operating temperatures ranged from 8 to $22^{\circ} \mathrm{C}$ and were nearly always $<20^{\circ} \mathrm{C}$. In the United States, membrane filtration processes are often performed at cool temperatures $\left(<20^{\circ} \mathrm{C}\right)$, primarily to reduce microbial growth. The DF was performed with $330 \mathrm{~L}$ of reverse osmosis filtered water to obtain permeate concentration averaging $4 \%$ TS, which was needed to reduce the lactose content required to produce MPC80. The UF retentate was cooled overnight to $<4^{\circ} \mathrm{C}$ and evaporated in 3 batches to 23,26 , and $28 \%$ TS $(19,21$, and $23 \%$ protein, respectively) with a custom-made, single-stage batch evaporator (Invensys APV, Tonawanda, NY). Lower protein concentrations were not studied, as these would be unattractive from an industrial viewpoint, and protein concentrations above $23 \%$ were challenging due to increased viscosity. The product inlet and outlet temperatures during evaporation were $\sim 38$ and $\sim 54^{\circ} \mathrm{C}$, respectively with a vacuum of $93 \mathrm{kPa}$. Concentration was by batch circulation mode. Maintaining temperatures at $<55^{\circ} \mathrm{C}$ during evaporation process was done to try to reduce whey protein denaturation. The total evaporation time varied with concentration, as protein concentrations of 19,21 , and $23 \%$ had a total evaporation time of 11 to 20,15 to 30 , and 21 to $36 \mathrm{~min}$, respectively. Concentrated milks were spray dried in a single-stage, natural gas direct-fired, pilot-scale spray drier (PSD 55, APV, Copenhagen, Denmark) equipped with 1 high-pressure hollow cone atomizer (model SIY 79, $0.368 \mathrm{~mm}$ diameter orifice with a SKY\#20 swirl, Spraying Systems, Wheaton IL). Just before atomization, concentrates were heated to $59^{\circ} \mathrm{C}$ with a double tube heat exchanger for an average of $9.5 \mathrm{~min}$ of hold time. Prior to spray drying, milk powder samples are often heated, which helps reduce viscosity for the atomization process as well as reduce the microbial load (Masters, 2002). To maintain similar moisture content in the MPC powders, the outlet air temperatures were 80,82 , and $84^{\circ} \mathrm{C}$ for the samples with 19,21 , and $23 \%$ protein concentrations in the concentrates, respectively. Inlet air temperature was kept constant at $176^{\circ} \mathrm{C}$.

\section{Manufacture of MPC by Different Processing Methods}

Pasteurized skim milk was UF and DF to $13 \%$ TS (10\% protein) in the concentrate and $3.7 \pm 0.1 \%$ average TS in the permeate using 6 UF elements, each $10.92 \mathrm{~cm}$ in diameter and $96.52 \mathrm{~cm}$ long, with a feed spacer of $2.03 \mathrm{~mm}$ (model MK-5B-4338-PHT, $30 \mathrm{kDa}$ molecular weight cutoff, Synder Filtration). The concentrate was divided into 2 equal portions. Half was cooled $\left(<4^{\circ} \mathrm{C}\right)$ overnight and then evaporated to 22.9 $\pm 0.1 \%$ TS (protein $19.2 \pm 0.2 \%$ ) with a custom-made, single-stage, batch evaporator (Invensys APV) and the other half was UF until it reached $23 \%$ TS $(19.0 \pm 0.2 \%$ protein) and permeate had $1.3 \pm 0.1 \%$ TS. Samples made with evaporation had a higher lactose content, so samples made with only UF/DF were standardized with rehydrated lactose powder to reach the same protein-to-lactose ratio as in the samples with evaporation. Lactose was rehydrated (approximately 6\%, wt/ vol solutions) and then added to the UF concentrate, agitated, and heated at $59^{\circ} \mathrm{C}$ for 9.5 min before spray drying. These preparation procedures ensured that lactose was fully dissolved before drying. Both types of concentrates were spray dried in a single-stage, natural gas direct-fired, pilot-scale spray dryer (model PSD 55, APV) fitted with 1 high-pressure hollow cone atomizer (model TDL4-18, 0.457-mm diameter orifice, Bete, Greenfield, MA). Concentrates were preheated $\left(59^{\circ} \mathrm{C}\right.$ for $9.5 \mathrm{~min}$ ) before drying. The inlet and outlet air temperatures were $180 \pm 2$ and $92 \pm 2^{\circ} \mathrm{C}$, respectively.

\section{Compositional Analyses}

The moisture, ash, total protein, and casein contents of the protein powders were determined according to AOAC International (2000) methods. The quantification of calcium was determined by using inductivelycoupled plasma emission spectroscopy (Vista-MPX Simultaneous ICP-OES; Varian Inc., Palo Alto, CA) using the wavelength $422.7 \mathrm{~nm}$. Soluble calcium was determined in UF permeate (Millipore Ultrafiltration membrane discs, Millipore Corporation, Billerica, MA; Ozcan et al., 2008) obtained from rehydrated powders (3.9\% protein). Bound calcium was estimated as total calcium minus soluble calcium. Fat content of the initial milk, or rehydrated powder (5\%, wt/wt, protein), was determined by the Mojonnier method (AOAC International, 2000). The amount of denatured protein that occurred during the processing of MPC was estimated using the method described by Guinee et al. (1995). The whey protein content was estimated from Kjeldahl analyses as the difference between true protein content and total casein content of the milk before processing (i.e., original whey protein content). The change in the whey protein content of the rehydrated MPC $(3.2 \%$, wt/wt, protein) after processing was considered to be due to denaturation (Guinee et al., 1995). Static laser light scattering was used to determine powder particle size distribution (Mastersizer S, Malvern Instruments Ltd., Malvern, UK). A dry powder feed attachment was used and the standard optical model presentation for particles dispersed in air was used. The average diameter of 3 measurements was calculated using the Mie and Fraunhofer theory and the volume-weighted mean diameter recorded. 
If rehydration was necessary for analyses, powders were rehydrated using a Waring Commercial Laboratory Blender (model 7012G, Waring Laboratory, Torrington, $\mathrm{CT}$ ) at $3,500 \mathrm{rpm}$ for $10 \mathrm{~min}$ at $30^{\circ} \mathrm{C}$, and then stirred with a 1-cm magnetic stirrer for $2 \mathrm{~h}$ at $20 \pm$ $2^{\circ} \mathrm{C}$. Rehydrated powder samples were stirred at $4^{\circ} \mathrm{C}$ overnight before analysis.

Sodium dodecyl sulfate-PAGE, under reducing and nonreducing conditions, was performed on rehydrated MPC (freshly produced), as previously described (Anema et al., 2006). Electrophoresis was performed with precast, 10 to $20 \%$ gradient polyacrylamide SDS-Gel (Bio-Rad Laboratories Inc., Richmond, CA) and run at $200 \mathrm{~V}$ in a Mini-Protean system (Bio-Rad Laboratories Inc.) using a Bio-Rad power supply unit (model 100/500, Bio-Rad Laboratories Inc.). The protein bands were washed with deionized water and stained with Coomassie Brilliant Blue R-250 Staining Solution (Bio-Rad Laboratories Inc.).

\section{Functionality Tests}

Bulk Density. The bulk powder density measurement method was adapted from IDF (1995). Powders $(50.0 \mathrm{~g})$ were weighed into a graduated $250-\mathrm{mL}$ glass cylinder and the volume was recorded after tapping 0 , 100, and 625 times using the Quantachrome Autotap (Quantachrome Instruments, AT-5, Boynton Beach, FL). Density analysis was performed every $30 \mathrm{~d}$ for 6 mo. Means of triplicates of initial density, loose density (100 tapings), and tapped bulk density (625 tapings) were calculated.

Solubility. Every $30 \mathrm{~d}$ for $6 \mathrm{mo}, 4.0 \mathrm{~g}$ of MPC powder that had been stored at $30^{\circ} \mathrm{C}$ was blended in 100 $\mathrm{mL}$ of deionized water $\left(30^{\circ} \mathrm{C}\right)$ with 3 drops of antifoam agent (Defoamer FG, Klenzade Inc., Rocklin, CA) in the Waring Commercial Laboratory 4-blade blender for 10 min. Twenty milliliters of the solution was centrifuged for $10 \mathrm{~min}$ at $2,455 \times g\left(21^{\circ} \mathrm{C}\right)$. The supernatant was decanted, the sample diluted with deionized water, and recentrifuged. The TS content in the remaining pellet of the tubes was compared with the TS content of the original solution. Insolubility (\%) was calculated by relating the quantity of insoluble powder in the tubes to the quantity of TS of solution $\times 100$, with the percent solubility of powders determined as $100-$ insolubility (\%).

Foaming. Foam overrun and stability were measured according to the method of Phillips et al. (1990) and the maximum yield stress method was adapted from Seibel et al. (2014). Foaming properties were measured in triplicate at time 0 and after every month that powders were stored at $30^{\circ} \mathrm{C}$. The MPC samples were rehydrated to a $5 \%$ protein (wt/wt) dispersion as described for the solubility test method. The $\mathrm{pH}$ was adjusted to 7.1, if necessary.

Viscosity. The MPC samples were rehydrated to a $5 \%$ protein $(\mathrm{wt} / \mathrm{wt}$ ) dispersion as described for the solubility test method. We included a standard commercial MPC sample manufactured by a US dairy company for comparison purposes (it had a similar composition to our experimental samples and was tested within $1 \mathrm{mo}$ of manufacture). Viscosity was determined at $25^{\circ} \mathrm{C}$ using a Universal Dynamic Spectrometer (Paar Physica, UDS 200, Physica Messtechnik GmbH, Stuttgart, Germany). Samples were sheared from 0 to $1,000 \mathrm{~s}^{-1}$ using the cup-and-bob measuring geometry (Z3 DIN, Physica Messtechnik GmbH), which consisted of 2 coaxial cylinders (diameters 25.0 and $27.5 \mathrm{~mm}$ ).

\section{Statistical Analysis}

Analyses were performed using JMP Pro (Version 10.0.0. SAS Institute Inc., Cary, NC). Significance indicated at $P<0.05$ was determined by ANOVA and Tukey's HSD tests. A split-plot design was applied to analyze the powder solubility data and foam stability, overrun, and maximum yield stress. A $3 \times 2$ completely randomized block design that incorporated all 3 protein contents of the feed $(19,21$, or $23 \%$ protein) or a $2 \times 2$ completely randomized block design that incorporated the 2 processing methods (UF/DF with evaporation or $\mathrm{UF} / \mathrm{DF}$ only) and 2 trial days were used for analysis of the response variables relating to MPC solubility. A split-plot design was used to monitor the effects of treatment (protein content or processing method) and storage time and their interactions on solubility and foam stability, overrun, and maximum yield stress. In the whole-plot factor, protein content or processing method were analyzed as discontinuous variables and trial day was blocked. For the subplot factor, storage time, and storage time $\times$ protein content or storage time $\times$ processing method were treated as variables. The interactive term protein content $\times$ trial, or processing method $\times$ trial, was treated as the error term for the protein content or processing method effect, respectively. The ANOVA for the split-plot design was carried out using Minitab (Version 16.0. Minitab Inc., State College, PA).

\section{RESULTS AND DISCUSSION}

\section{Composition and Physical Properties}

All experimental MPC samples produced in our study had a protein content (as-is basis) of about $80 \%$ (wt/wt; Table 1). Within treatments, the gross composition of powders was similar. Total $\mathrm{Ca}$, moisture, 
Table 1. Mean $( \pm \mathrm{SD})$ composition $(\mathrm{n}=3)$ and properties of milk protein concentrate $(\mathrm{MPC})$ powders produced with different processing methods, and from evaporator concentrates with different protein contents (before spray drying) ${ }^{1}$

\begin{tabular}{|c|c|c|c|c|c|}
\hline Item & UF/DF only & $\begin{array}{l}\text { UF/DF with } \\
\text { evaporation }\end{array}$ & 19 & 21 & 23 \\
\hline $\mathrm{CP}(\% \mathrm{wt} / \mathrm{wt})$ & $79.4^{\mathrm{a}} \pm 0.9$ & $80.0^{\mathrm{a}} \pm 1.7$ & $80.2^{\mathrm{A}} \pm 0.7$ & $80.6^{\mathrm{A}} \pm 1.1$ & $80.7^{\mathrm{A}} \pm 1.2$ \\
\hline $\begin{array}{l}\text { Increase in denatured whey protein } \\
\text { content compared with milk (\% wt/wt) }\end{array}$ & $6.6^{\mathrm{a}} \pm 2.3$ & $14.9^{\mathrm{b}} \pm 3.4$ & $27.1^{\mathrm{A}} \pm 1.2$ & $25.1^{\mathrm{A}} \pm 1.3$ & $26.3^{\mathrm{A}} \pm 1.2$ \\
\hline Moisture (\% wt/wt) & $5.07^{\mathrm{a}} \pm 0.08$ & $5.43^{\mathrm{b}} \pm 0.40$ & $3.7^{\mathrm{A}} \pm 0.15$ & $3.5^{\mathrm{A}} \pm 0.15$ & $3.5^{\mathrm{A}} \pm 0.24$ \\
\hline Lactose $(\% \mathrm{wt} / \mathrm{wt})$ & $7.9^{\mathrm{a}} \pm 1.4$ & $6.1^{\mathrm{a}} \pm 2.3$ & $7.3^{\mathrm{A}} \pm 2.0$ & $7.6^{\mathrm{A}} \pm 1.7$ & $8.8^{\mathrm{A}} \pm 1.9$ \\
\hline Total Ca $(\mathrm{mg} / 100 \mathrm{mg})$ & $2,007^{\mathrm{a}} \pm 73$ & $2,143^{\mathrm{b}} \pm 93$ & $1,939^{\mathrm{A}} \pm 78$ & $1,983^{\mathrm{A}} \pm 50$ & $1,929^{\mathrm{A}} \pm 68$ \\
\hline Powder particle size (D43) $(\mu \mathrm{m})$ & $57^{\mathrm{a}} \pm 8$ & $57^{\mathrm{a}} \pm 11$ & $31^{\mathrm{A}} \pm 2$ & $37^{\mathrm{AB}} \pm 0.9$ & $50^{\mathrm{B}} \pm 24$ \\
\hline
\end{tabular}

${ }^{\mathrm{a}, \mathrm{b}}$ Means within the same row with a different lowercase superscript differ $(P<0.05$; comparing the effect of MPC processing method, i.e., produced with either UF/DF only or UF/DF and evaporation).

${ }_{\mathrm{A}, \mathrm{B}}$ Means within the same row with a different uppercase superscript differ $(P<0.05$; comparing the effect of MPC produced with different protein content in the feed).

${ }^{1}$ Values are the means of data from triplicate analysis (as-is basis). DF $=$ diafiltered.

fat and ash contents were the same $(P>0.05)$ in the MPC powder samples produced with a variation of the protein concentration of the concentrate. The powders produced using only the UF/DF concentration method exhibited a lower ash and total Ca content compared with samples that were also evaporated. Rehydrated MPC (3.9\% protein) made with only UF/DF also had a significantly lower bound $\mathrm{Ca}$ content than samples that were also evaporated (results not shown). More extensive UF/DF likely allowed soluble minerals to permeate the UF membrane. Some solubilization of CCP may also occur during UF and extensive DF, as reported previously (Singh, 2007; Ferrer et al., 2011).

The percentage of denatured whey protein did not change with increasing protein content in the concentrate (Table 1). The SDS-PAGE results of rehydrated MPC (tested immediately after manufacture) produced from concentrates with various protein contents are shown in Figure 1. No increase in protein aggregation was observed with the different protein contents (in agreement with the whey protein denaturation results; Table 1). Any variation in functionalities between concentrates made with different protein concentrations was not likely caused by the differences in denaturation of whey proteins. Havea (2006) reported that disulfidelinked whey protein-casein aggregates were present in various experimental MPC powders, but that they did not appear to play a major role in powder insolubility. The percentage of denatured whey protein was higher in samples made by including evaporation as a concentration method (Table 1). Presumably, this reflects denaturation resulting from the thermal processing involved in evaporation, although temperatures were maintained at $<55^{\circ} \mathrm{C}$. Another possibility is greater shear-induced denaturation in the evaporator due to the batch recirculation mode of operation. We also performed SDS-PAGE on the MPC produced with the different concentration methods (Figure 2); no visible differences in denatured protein aggregates could be detected in the lanes or bands of the freshly manufactured MPC samples.

The viscosity measurements of the rehydrated MPC that were made from concentrates with different protein contents are shown in Figure 3. The viscosity increased with increasing protein content of the concentrates. The commercial MPC, as well as the sample made from the $19 \%$ protein concentrate, had significantly lower viscosities than samples made from the higher protein concentrates.

The particle size of the powders from the 2 different treatments (protein concentration of the concentrate and processing method) should not be compared, as 2 different atomizers were used in these treatments. Similar particle sizes were observed for samples with different concentration methods (Table 1). We noted an increase in the particle size of powders with an increase in the protein content of the concentrate (Table 1 ), in agreement with the results reported by Park et al. (2016). With an increase in the protein content of the concentrate, we found an increase in viscosity (Figure 3). The viscosity of concentrated skim milk also increases drastically with an increase in protein content (Snoeren et al., 1984; Patel et al., 2009). The viscosity of the concentrate before spray drying has a marked effect on powder properties, independent of TS and denaturation of whey proteins. A high viscosity impedes the formation of small droplets in the atomizer of the spray dryer (Walstra et al., 2006), and thereby modifies powder properties, such as particle size and bulk density (Masters, 2002). Wu et al. (2014) spray 


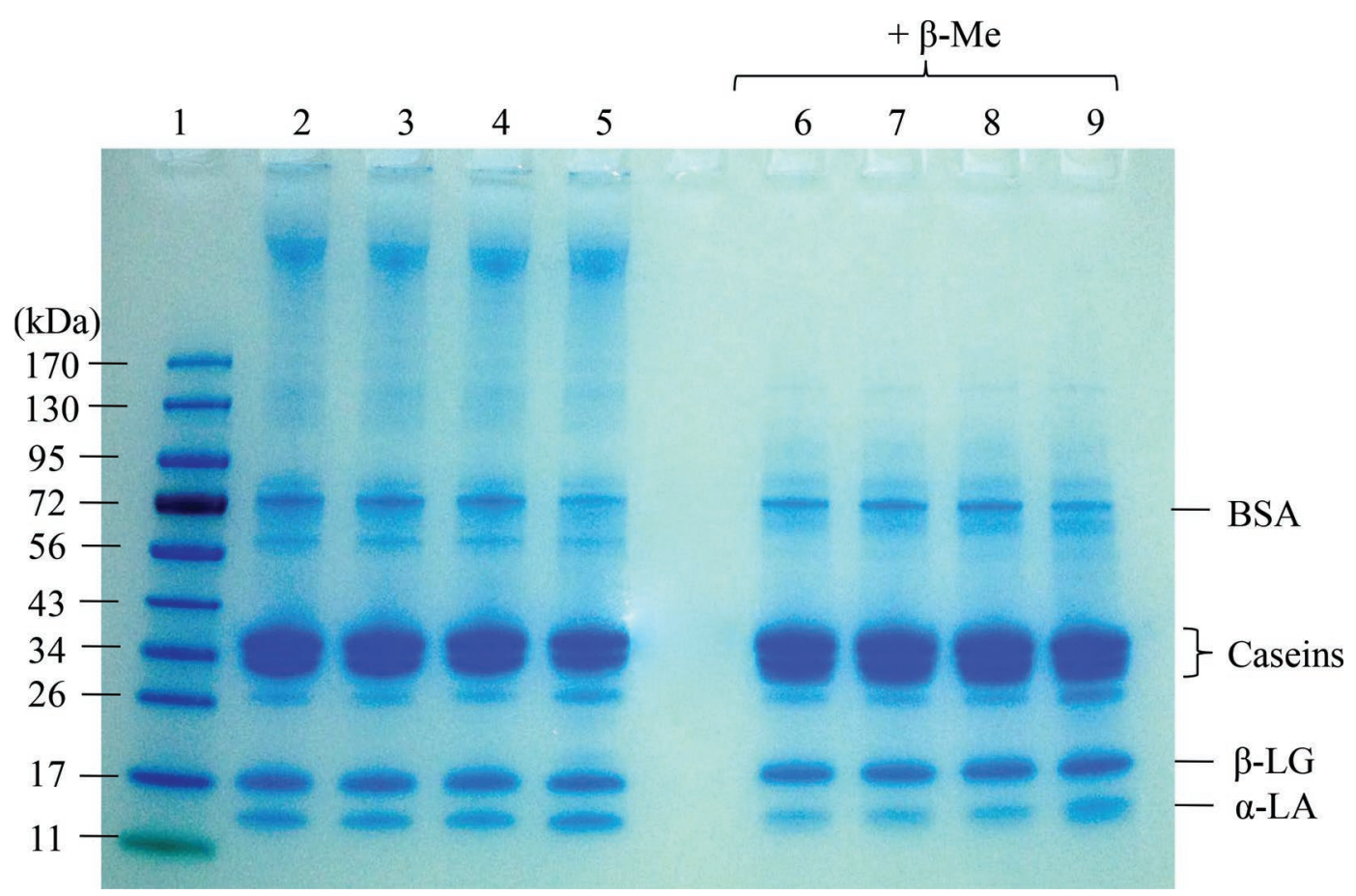

Figure 1. Sodium dodecyl sulfate-PAGE of fresh, rehydrated milk protein concentrate (MPC) powder produced with various protein contents in the concentrate. Lane 1: protein marker (molecular weight standards); lane 2: skim milk powder; lane 3: MPC from 19\% protein in the concentrate; lane 4: MPC from 21\% protein in the concentrate; lane 5: MPC from $23 \%$ protein in the concentrate; lane 6: skim milk powder with $\beta$-mercaptoethanol $(\beta-\mathrm{Me})$; lane 7: MPC from $19 \%$ protein in the concentrate with $\beta$-mercaptoethanol; lane 8 : MPC from $21 \%$ protein in the concentrate with $\beta$-mercaptoethanol; lane 9: MPC from $23 \%$ protein in the concentrate with $\beta$-mercaptoethanol. Color version available online.

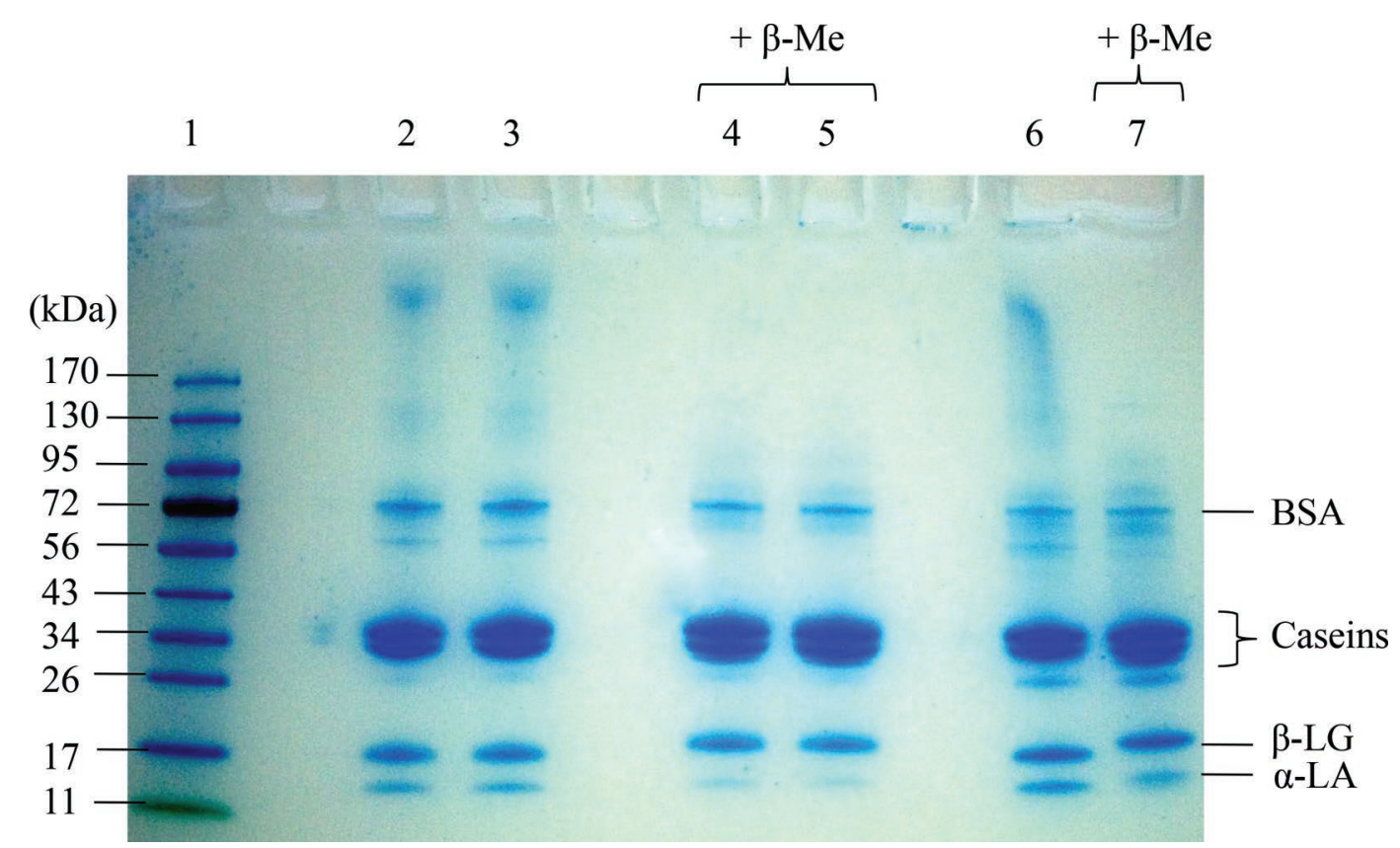

Figure 2. Sodium dodecyl sulfate-PAGE of fresh, rehydrated milk protein concentrate (MPC) powder produced with or without evaporation. Lane 1: molecular weight standard; lane 2: MPC produced with UF and diafiltration (DF) and evaporation; lane 3: MPC produced with UF/DF only; lane 4: MPC produced with UF/DF and evaporation with added $\beta$-mercaptoethanol ( $\beta$-Me); lane 5: MPC produced with UF/DF only with added $\beta$-mercaptoethanol; lane 6: skim milk powder; lane 7: skim milk powder with added $\beta$-mercaptoethanol. Color version available online. 
dried reconstituted skim milk powder with high feed TS concentrations (up to 53.5, wt/wt, \%) and studied the powder surface composition and solubility. Those authors found that protein migration to the powder surface of the particles was retarded by the higher TS content, but the surface fat proportion was not affected by the protein concentration of the concentrate. Lower concentrate viscosity leads to less energy consumption during atomization (Patel et al., 2009). A high protein content in the concentrate could increase the number or strength of casein-casein interactions and, therefore, modify the surface composition of powder particles due to a change in their drying behavior (Fu et al., 2012).

Similar bulk (tapped) powder density was observed for samples with the different concentration methods (Figure 4), in agreement with their similar particle sizes (Table 1). We noted an increase in the bulk density of powders with an increase in the protein content of the concentrate (Figure 4). Bulk density did not change over time for any of the samples. Masters (2002) indicated that an increase in feed TS usually increases the bulk density of powders. The bulk density of milk powders is a very important property for the industry due to economical and practical reasons, as a high bulk density reduces shipping and storage costs (Masters, 2002). Crowley et al. (2014) reported that as the final protein content of MPC powders increased that the bulk density decreased due to increased levels of interstitial and occluded air. For the manufacture of higher-protein MPC powders, feed materials with lower viscosity and TS were used by Crowley et al. (2014), which helped to decrease particle size.

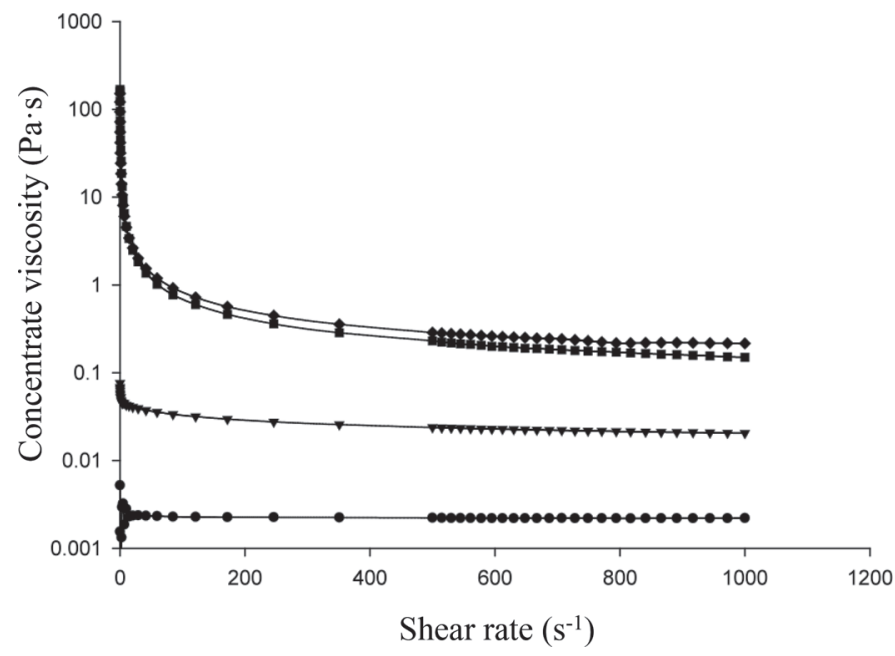

Figure 3. Viscosity measurements (means, $\mathrm{n}=2$ ) tested at $25^{\circ} \mathrm{C}$ for commercial milk protein concentrate (MPC) at $80 \%$ protein rehydrated to $5 \%$ ( ) protein and experimental MPC concentrates after evaporation to $19(\boldsymbol{\nabla}), 21(\boldsymbol{\square})$, and $23 \%(\bullet)$ protein before spray drying.

\section{Solubility}

The solubility of MPC was not significantly affected by the protein content of the spray dryer feed (Table 2); evaporation or extended UF had similar effects on the solubility of MPC (Table 3). The solubility of all MPC samples decreased significantly $(P<0.001)$ during 6 mo of storage at $30^{\circ} \mathrm{C}$ (Tables 2 and 3). Skim milk powder powders produced with a higher feed TS content showed faster wettability, but lower overall solubility (Wu et al., 2014). Augustin et al. (2012) prepared MPC powders from concentrates that had $23(18.4 \%$ protein), 25 (20.9\% protein), and $31 \%$ TS (25.4\% protein) by using UF, UF/DF, and UF with evaporation, respectively. Augustin et al. (2012) found that initial solubility of MPC decreased with increasing TS of the concentrates. In our study, the MPC produced with $23 \%$ protein concentrate exhibited the lowest solubility for most of the high-temperature storage period, although we noted little difference between the solubility for the other 2 protein concentrations (Figure 5). Initial solubility levels were lower for the samples in the concentration methods treatment compared with those made with different concentrations of protein in the concentrates. These 2 treatments were made on different dates and with different processing conditions. Our initial solubility levels $(\geq 70 \%)$ were higher than some previous reports for MPC (Havea, 2006; Sikand et al., 2013). In the study of Augustin et al. (2012), the highest solubility was observed for the UF-only sample, which also had the lowest protein content in the powder and the highest lactose content (as no DF was used). Increasing the concentration of lactose in MPC improves the solubility and wettability of powder (Baldwin, 2010). In our study, all the protein treatment samples had similar protein and lactose contents in the powders (Table 1), avoiding this confounding factor for rehydration or solubility.

The MPC made from the concentrate with $23 \%$ protein also had larger powder particles (Table 1). Larger particles could possibly contribute to the extended rehydration time, as several studies (e.g., Richard et al., 2013) reported that the slow dispersion of primary particles is the reason for prolonged rehydration time. Mimouni et al. (2010b) found that MPC at $85 \%$ protein allowed rapid water penetration into the particle, but still exhibited poor reconstitution properties. Lactose, whey proteins and soluble minerals were released very quickly from the core of the particle, whereas casein micelles and associated minerals dissolved very slowly from the surface.

The MPC produced with different protein concentrations for the concentrates showed a marked decrease in solubility in the first 2 mo and reached a plateau 


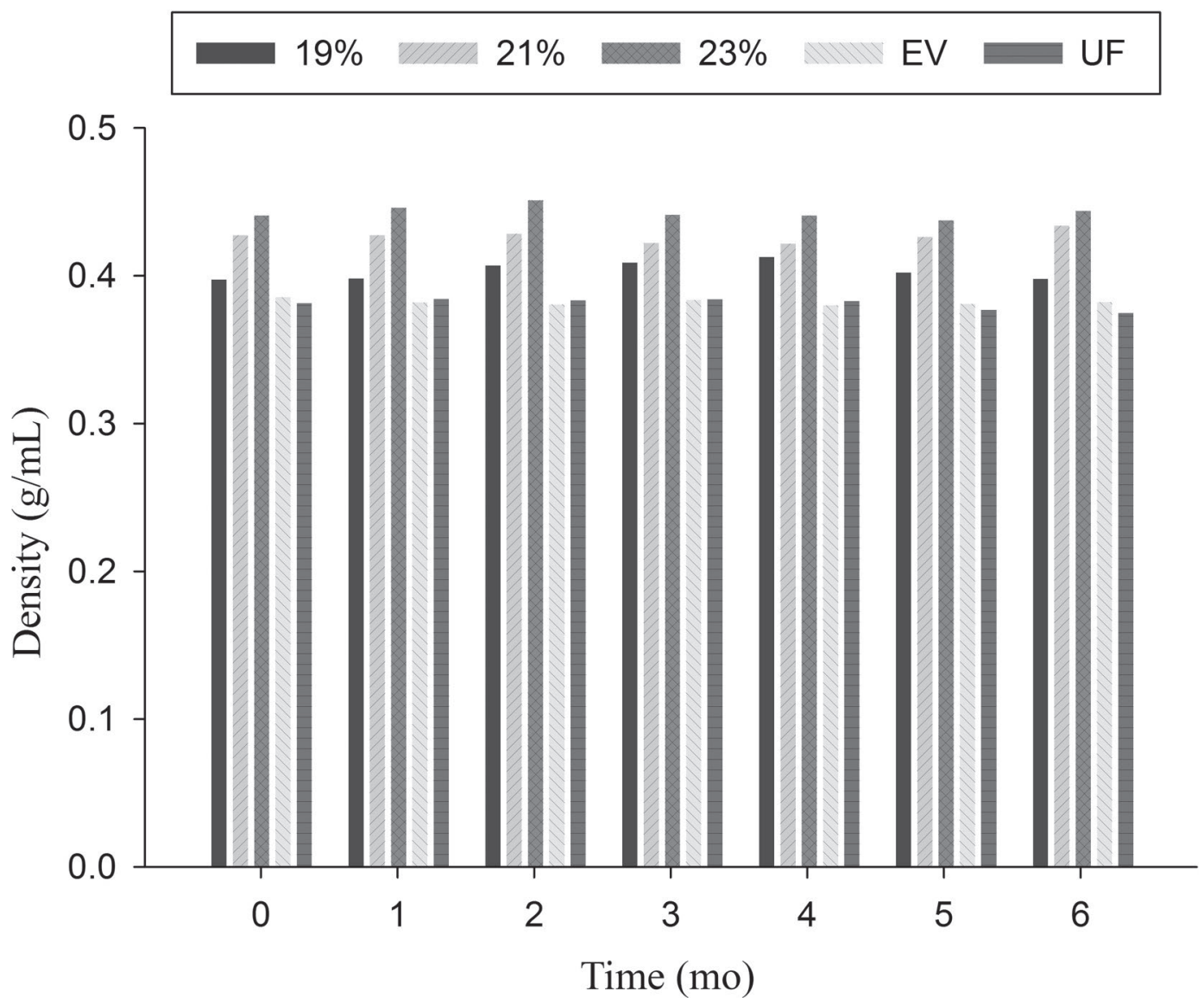

Figure 4. Bulk density measured after 625 taps of experimental milk protein concentrate (MPC) produced from concentrates with 19, 21 , or $23 \%$ protein content and with UF or diafiltration (DF) and evaporation (EV) or with UF/DF only (UF). Powders were stored at $30^{\circ} \mathrm{C}$ for 6 mo. Values are means $\pm \mathrm{SD}$ of data from triplicate analysis.

value (Figure 5). The MPC sample produced from the concentrate with $23 \%$ protein exhibited the steepest decrease in solubility the first 2 mo of high-temperature storage. Anema et al. (2006) also found a rapid decrease in solubility in the first month of MPC80 stored at $35^{\circ} \mathrm{C}$, which thereafter plateaued. Anema et al. (2006) suggested that caseins accounted for most of the insoluble material formed over storage time, most likely by cross-linking of the proteins. It is likely that the higher protein content in the concentrate increased the close

Table 2. Probabilities and $\mathrm{R}^{2}$ values for solubility, foam stability, overrun, and maximum yield stress of experimental milk protein concentrate produced from concentrates with different protein contents $(19,21$, and $23 \%$ protein) during 6 mo of storage at $30^{\circ} \mathrm{C}^{1}$

\begin{tabular}{lrrccc}
\hline Factor & df & Solubility & Stability & Overrun & Maximum yield stress \\
\hline Whole plot & 2 & 0.098 & 0.134 & 0.899 & 0.747 \\
$\quad \begin{array}{l}\text { Protein content (PC) } \\
\text { Trial (t) }\end{array}$ & 1 & 0.198 & 0.186 & 0.863 & 0.180 \\
$\quad$ Error (t $\times$ PC) & 2 & & & & \\
$\quad$ Split-plot & 6 & $<0.001$ & 0.003 & 0.007 & 0.001 \\
$\quad$ Storage time (S) & 12 & 1.000 & 0.154 & 0.926 & 0.673 \\
$\quad$ S PC & 18 & 0.87 & 0.78 & 0.66 & 0.77 \\
$\quad$ Error & & &
\end{tabular}

${ }^{1}$ Split plot design was analyzed according to Montgomery (2005). Three treatments (19, 21, and $23 \%$ protein in the concentrates) were analyzed as a discontinuous variable and the trials were blocked $(3 \times 2$ blocked design $)$. Subplot included the effect of the storage time, and storage time $\times$ protein content as variable on experimental milk protein concentrate with $80 \%$ protein content. 


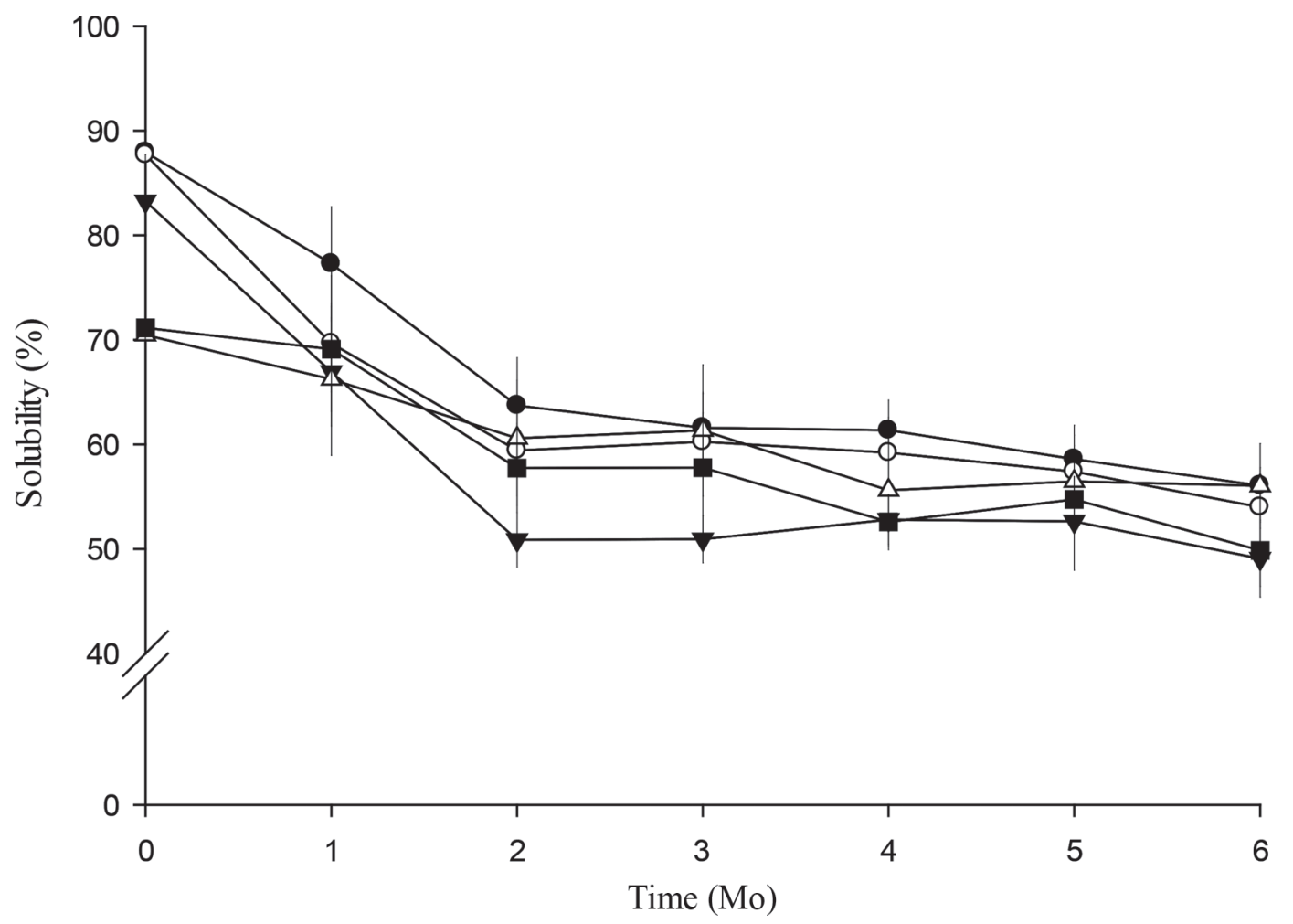

Figure 5. Solubility of milk protein concentrate (MPC) powder from samples produced $(\mathrm{n}=2)$ with concentrates with protein concentrations of $19(\bullet), 21(\bigcirc)$ or $23 \%(\boldsymbol{\nabla})$, and with UF or diafiltration $(\mathrm{DF})$ and evaporation $(\Delta)$ and from UF/DF only $(\boldsymbol{\square})$, over a period of 6 mo storage at $30^{\circ} \mathrm{C}$. Values are means $\pm \mathrm{SD}$ of data from triplicate analysis.

packing of caseins within powder particles, and that over time some type of interactions between caseins was enhanced. The reason for the steep decrease of solubility during the first 2 mo can only be speculated.

The UF/DF combined with evaporation or UF/ $\mathrm{DF}$ alone resulted in a different ash content, but that did not have a large effect on the solubility of the experimental MPC, as shown in Table 3. The decrease in minerals after DF might not have been large enough to have a long-lasting effect on the properties of the proteins. We observed only a small decrease $(<7 \%)$ in total calcium levels in the powders made UF/DF only compared with the inclusion of evaporation (Table 1). We are aware of reports of calcium-depleted MPC powders with higher solubility; for example, Bhaskar et al. (2007) replaced sodium with calcium ions using an ion-exchange method, resulting in MPC with higher solubility. A calcium reduction of $33 \%$ was sufficient to

Table 3. Probabilities and $\mathrm{R}^{2}$ values for solubility, foam stability, overrun, and maximum yield stress of experimental milk protein concentrate produced with UF or diafiltration (DF) and evaporation or UF/DF only during 6 mo of storage at $30^{\circ} \mathrm{C}^{1}$

\begin{tabular}{|c|c|c|c|c|c|}
\hline Factor & df & Solubility & Stability & Overrun & Maximum yield stress $(\mathrm{Pa})$ \\
\hline \multicolumn{6}{|l|}{ Whole plot } \\
\hline Processing method (PM) & 1 & 0.642 & 0.344 & 0.588 & 0.455 \\
\hline Trial $(\mathrm{t})$ & 1 & 0.547 & 0.125 & 0.294 & 0.079 \\
\hline Error $(\mathrm{t} \times \mathrm{PM})$ & 1 & & & & \\
\hline \multicolumn{6}{|l|}{ Split-plot } \\
\hline Storage time (S) & 6 & $<0.001$ & 0.027 & 0.163 & 0.564 \\
\hline $\mathrm{S} \times \mathrm{PM}$ & 6 & 0.607 & 0.304 & 0.591 & 0.492 \\
\hline Error & 12 & & & & \\
\hline $\mathrm{R}^{2}$ & & 0.93 & 0.84 & 0.76 & 0.70 \\
\hline
\end{tabular}

${ }^{1}$ Split plot design was analyzed according to Montgomery (2005). Two treatments (UF/DF and evaporation or UF/DF only) were analyzed as a discontinuous variable and the trials were blocked $(2 \times 2$ blocked design). Subplot included the effect of the storage time, and storage time $\times$ processing method as variable on experimental milk protein concentrate with $80 \%$ protein content. 
see an improvement in MPC solubility (Bhaskar et al., 2007). Mao et al. (2012) produced MPC with the addition of $\mathrm{NaCl}$ during the DF step and reported marked increased solubility with higher $\mathrm{NaCl}$ concentration. These results suggested that a large loss of bound calcium (i.e., sufficient to cause disruption of casein micelles) may contribute to an improved solubility of high-protein powders. Sikand et al. (2013) reported that $\mathrm{NaCl}$ addition during the DF step resulted in a $25 \%$ reduction in total calcium content in MPC (80\%), which contributed to a significant improvement in solubility. The inclusion of evaporation resulted in MPC with a small increase $(\sim 7 \%)$ in total calcium content (Table 1), but that change in the calcium content did not significantly affect its solubility compared with the $\mathrm{UF} / \mathrm{DF}$ sample.

Cao et al. (2015) reported that MPC (61\% protein) concentrated with evaporation had poorer solubility compared with samples concentrated before spray drying by nanofiltration. However, significant differences were found in the composition of these 2 treatments, the protein concentrations in the concentrates prepared by nanofiltration and evaporation were 14.3 and $18.0 \%$, respectively (Cao et al., 2015). The significantly higher TS and protein concentrations in the MPC manufactured with evaporation could have contributed to its lower solubility, as reported by Cao et al. (2015).

\section{Foaming Properties}

During the initial storage period, significantly higher $(P<0.05)$ foam stability was observed for MPC produced from the concentrate with $23 \%$ protein compared with foams made with MPC produced with $19 \%$ protein (Figure 6b). Foaming properties significantly decreased $(P<0.05)$ after storage at $30^{\circ} \mathrm{C}$ for 6 mo (Table 2$)$, which might be correlated with the concurrent decrease in powder solubility during this storage time (Figure 5). High protein solubility is usually considered a requirement for milk powders to exhibit good foaming (Huppertz, 2010). All rehydrated MPC produced from concentrates with various protein contents showed similar foam overrun and maximum yield stress values, as can be seen in Figure 6a and 6c, respectively; however, less stability $(P<0.05)$ was observed after 6 mo storage of all MPC powders stored at $30^{\circ} \mathrm{C}$ (Figure 6b). Maximum yield stress, which was measured by converting torque readings from a viscometer into yield stress, has been suggested to be a good index of foam stiffness (Pernell et al., 2000; Seibel et al., 2014). The MPC powders produced with evaporation or with extended UF only exhibited similar foam stability, overrun, and maximum yield stress (Table 3, Figure 7 ). The foam stability of powders produced by the different concentration methods decreased significantly $(P<0.05)$ during powder storage at $30^{\circ} \mathrm{C}$ (Table 3; Figure 7). No significant effect of storage time was observed for foam overrun or maximum yield stress values of MPC samples made with different processing methods (Table 3 ).
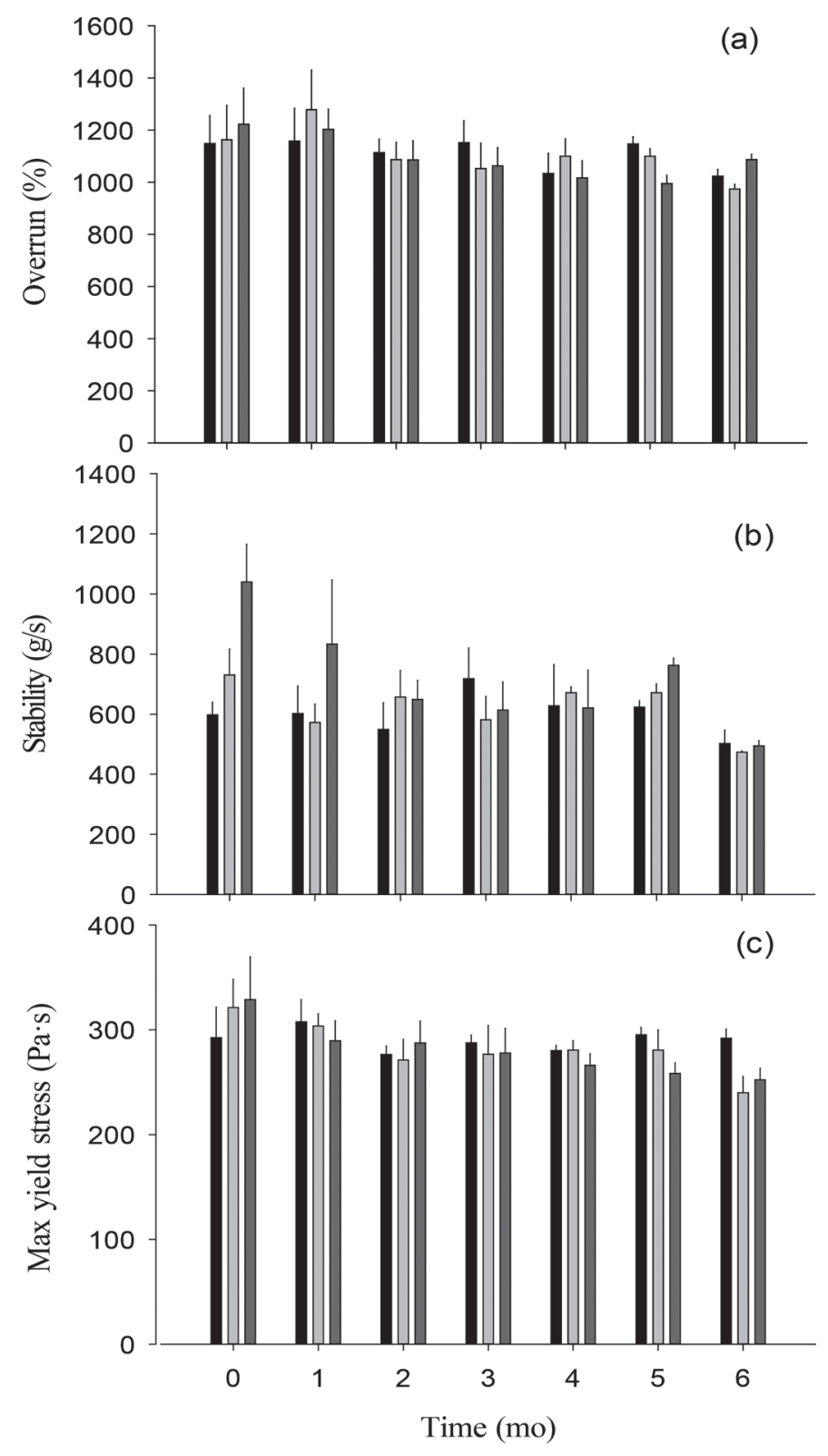

Figure 6. Foam overrun (a), foam stability (b), and maximum yield stress of foams (c) of experimental milk protein concentrate (MPC) produced from concentrates with 19 (black), 21 (light gray), or $23 \%$ (dark gray) protein content. Samples were rehydrated to a $5 \%$ protein solution (wt $/ \mathrm{vol}$ ). Powders were stored at $30^{\circ} \mathrm{C}$ for $6 \mathrm{mo}$. Values are means \pm SD of data from triplicate analysis. 

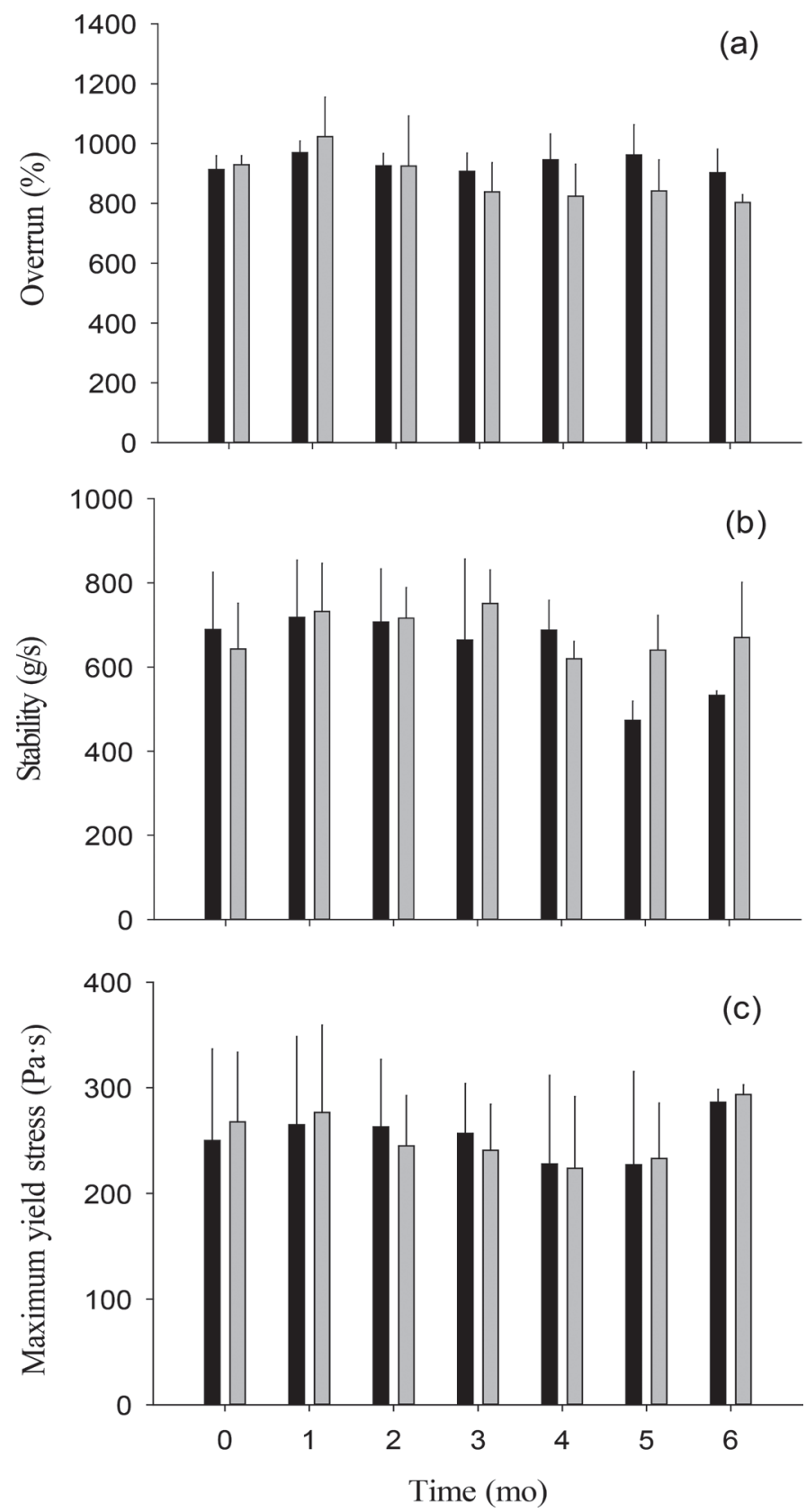

Figure 7. Foam overrun (a), foam stability (b), and maximum yield stress of foams (c) of experimental milk protein concentrate (MPC) produced with UF or diafiltration (DF) and evaporation (black) or with UF/DF only (gray). Samples were rehydrated to a $5 \%$ protein solution (wt/vol). Powders were stored at $30^{\circ} \mathrm{C}$ for 6 mo. Values are means \pm SD of data from triplicate analysis.

\section{CONCLUSIONS}

This study demonstrated that the manufacture of MPC from concentrates with 3 different protein concentrations did not significantly influence solubility, although we did note a trend of lower solubility in the highest protein content (23\%) sample. All powders exhibited a significant decrease in solubility during high-temperature storage with the largest decrease during the first 2 mo. The method we used to determine solubility consisted of high shear mixing treatment for $10 \mathrm{~min}$; it is possible that our methodology resulted in smaller solubility differences observed between treatments. Increasing the protein content of concentrates likely resulted in increased viscosity, which would have impeded the formation of smaller droplets during atomization. The higher bulk density of powders made from higher-protein concentrates could be due to their larger particle size (if the porosity was the same). Foaming properties were not significantly different between the 3 protein concentrate treatments, presumably due to their similar final powder compositions and solubility behavior. Foaming properties decreased during powder storage, presumably due to the reduction in protein solubility. We found no significant difference in the functionalities of MPC samples produced with UF/DF combined with evaporation or with UF/DF only. The MPC samples made with addition of the evaporation step had a significantly higher level of denatured whey protein, presumably due to thermal processing during evaporation. The MPC samples made with UF/DF had lower ash and total calcium content than the samples made with the addition of the evaporation. Presumably, the more extensive UF and DF processing needed without the inclusion of evaporation resulted in greater losses of soluble minerals. Although the 2 processing methods slightly modified the mineral contents of the MPC powders, we found no significant difference in their solubility behavior.

\section{ACKNOWLEDGMENTS}

The funding support of National Dairy Council (Rosemont, IL) and the Dairy Farmers of Wisconsin (Madison, WI) is greatly appreciated.

\section{REFERENCES}

Agarwal, S., R. L. W. Beausire, S. Patel, and H. Patel. 2015. Innovative uses of milk protein concentrates in product development. J. Food Sci. 80:A23-29.

Anema, S. G., D. N. Pinder, R. J. Hunter, and Y. Hemar. 2006. Effects of storage temperature on the solubility of milk protein concentrate (MPC85). Food Hydrocoll. 20:386-393.

AOAC International. 2000. Official Methods of Analysis. 17th ed. AOAC International, Gaithersburg, MD.

Augustin, M. A., P. Sanguansri, R. Williams, and H. Andrews. 2012 High shear treatment of concentrates and drying conditions influence the solubility of milk protein concentrate powders. J. Dairy Res. 79:459-468.

Baldwin, A. J. 2010. Insolubility of milk powder products-A mini review. Dairy Sci. Technol. 90:169-179.

Bhaskar, G. V., H. Singh, and N. D. Blazey, inventors. 2007. Milk protein products and processes. New Zealand Dairy Board, assignee. US Pat. No. 7,157,108. 
Cao, J., W. Zhang, S. Wu, C. Liu, Y. Li, H. Li, and L. Zhang. 2015. Effects of nanofiltration and evaporation on the physiochemical properties of milk protein during processing of milk protein concentrate. J. Dairy Sci. 98:100-105.

Crowley, S. V., B. Desautel, I. Gazi, A. L. Kelly, T. Huppertz, and J. A. O'Mahony. 2015. Rehydration characteristics of milk protein concentrate powders. J. Food Eng. 149:105-113.

Crowley, S. V., I. Gazi, A. L. Kelly, T. Huppertz, and J. A. O’Mahony. 2014. Influence of protein concentration on the physical characteristics and flow properties of milk protein concentrate powders. J. Food Eng. 135:31-38.

DeCastro, M., and W. J. Harper. 2003. Effect of retentate heat treatment and spray dryer inlet temperature on the properties of milk protein concentrate. Milchwissenschaft 58:13-15.

Fang, Y., S. Rogers, C. Selomulya, and X. D. Chen. 2012. Functionality of milk protein concentrate: Effect of spray drying temperature. Biochem. Eng. J. 62:101-105.

Ferrer, M. A., M. Alexander, and M. Corredig. 2011. Does ultrafiltration have a lasting effect on the physico-chemical properties of the casein micelles? Dairy Sci. Technol. 91:151-170.

Fu, N., M. W. Woo, C. Selomulya, X. D. Chen, K. Patel, P. Schuck, and R. Jeantet. 2012. Drying kinetics of skim milk with 50 wt. \% initial solids. J. Food Eng. 109:701-711.

Fyfe, K. N., O. Kravchuk, T. Le, H. C. Deeth, A. V. Nguyen, and B. Bhandari. 2011. Storage induced changes to high protein powders: influence on surface properties and solubility. J. Sci. Food Agric. 91:2566-2575.

Gaiani, C., M. Morand, C. Sanchez, E. A. Tehrany, M. Jacquot, P. Schuck, R. Jeantet, and J. Scher. 2010. How surface composition of high milk proteins powders is influenced by spray-drying temperature. Colloids Surf. B Biointerfaces 75:377-384.

Gaiani, C., P. Schuck, J. Scher, S. Desobry, and S. Banon. 2007. Dairy powder rehydration: Influence of protein state, incorporation mode, and agglomeration. J. Dairy Sci. 90:570-581.

Gaiani, C., P. Schuck, J. Scher, J. J. Ehrhardt, E. Arab-Tehrany, M. Jacquot, and S. Banon. 2009. Native phosphocaseinate powder during storage: Lipids released onto the surface. J. Food Eng. 94:130-134.

Guinee, T. P., P. D. Pudja, W. J. Reville, D. Harrington, E. O. Mulholland, M. Cotter, and T. M. Cogan. 1995. Composition, microstructure and maturation of semi-hard cheeses from high protein ultrafiltered milk retentates with different levels of denatured whey proteins. Int. Dairy J. 5:543-568.

Haque, E., B. R. Bhandari, M. J. Gidley, H. C. Deeth, and A. K. Whittaker. 2011. Ageing-induced solubility loss in milk protein concentrate powder: effect of protein conformational modifications and interactions with water. J. Sci. Food Agric. 91:2576-2581.

Havea, P. 2006. Protein interactions in milk protein concentrate powders. Int. Dairy J. 16:415-422.

Huppertz, T. 2010. Foaming properties of milk: A review of the influence of composition and processing. Int. J. Dairy Technol. 63:477488.

IDF. 1995. Dried milk and dried milk products - Determination of bulk density. Standard 134A, International Dairy Federation (IDF), Brussels, Belgium.

Li, K., M. W. Woo, H. Patel, L. Metzger, and C. Selomulya. 2018. Improvement of rheological and functional properties of milk protein concentrate by hydrodynamic cavitation. J. Food Eng. 221:106113.

Mao, X. Y., P. S. Tong, S. Gualco, and S. Vink. 2012. Effect of $\mathrm{NaCl}$ addition during diafiltration on the solubility, hydrophobicity, and disulfide bonds of $80 \%$ milk protein concentrate powder. J. Dairy Sci. 95:3481-3488.

Masters, K. 2002. Spray Drying in Practice. SprayDryConsult International ApS, Charlottelund, Denmark.
McCarthy, N. A., O. Power, H. B. Wijayanti, P. M. Kelly, L. Mao, and M. A. Fenelon. 2017. Effects of calcium chelating agents on the solubility of milk protein concentrate. Int. J. Dairy Technol. 70:415-423.

Mimouni, A., H. C. Deeth, A. K. Whittaker, M. J. Gidley, and B. R. Bhandari. 2010a. Investigation of the microstructure of milk protein concentrate powders during rehydration: alterations during storage. J. Dairy Sci. 93:463-472.

Mimouni, A., H. C. Deeth, A. K. Whittaker, M. J. Gidley, and B. R. Bhandari. 2010b. Rehydration of high-protein-containing dairy powder: Slow- and fast-dissolving components and storage effects. Dairy Sci. Technol. 90:335-344.

Mistry, V. V., and H. N. Hassan. 1991. Delactosed, high milk protein powder. 1. Manufacture and composition. J. Dairy Sci. 74:11631169.

Montgomery, D. C. 2005. Design and Analysis of Experiments. 6th ed. John Wiley \& Sons Inc., Hoboken, NJ.

Ozcan, T., D. S. Horne, and J. A. Lucey. 2008. Effect of tetrasodium pyrophosphate on the physicochemical properties of yogurt gels. J. Dairy Sci. 91:4492-4500.

Park, C. W., M. A. Stout, and M. A. Drake. 2016. The effect of spraydrying parameters on the flavor of nonfat dry milk and milk protein concentrate 70\%. J. Dairy Sci. 99:9598-9610.

Patel, R. P., M. P. Patel, and A. M. Suthar. 2009. Spray drying technology: an overview. Indian J. Sci. Technol. 2:44-47.

Pernell, C. W., E. A. Foegeding, and C. R. Daubert. 2000. Measurement of the yield stress of protein foams by vane rheometry. J. Food Sci. 65:110-114.

Phillips, L. G., J. B. German, T. E. O'Neill, E. A. Foegeding, V. R. Harwalkar, A. Kilara, B. A. Lewis, M. E. Mangino, C. V. Morr, J. M. Regenstein, D. M. Smith, and J. E. Kinsella. 1990. Standardized procedure for measuring foaming properties of three proteins, a collaborative study. J. Food Sci. 55:1441-1444, 1453.

Richard, B., J. F. Le Page, P. Schuck, C. Andre, R. Jeantet, and G. Delaplace. 2013. Towards a better control of dairy powder rehydration processes. Int. Dairy J. 31:18-28.

Seibel, J. R., M. S. Molitor, and J. A. Lucey. 2014. Properties of casein concentrates containing various levels of beta-casein. Int. J. Dairy Technol. 67:1-6.

Sikand, V., P. S. Tong, and J. Walker. 2013. Effect of adding salt during the diafiltration step of milk protein concentrate powder manufacture on mineral and soluble protein composition. Dairy Sci. Technol. 93:401-413.

Singh, H. 2007. Interactions of milk proteins during the manufacture of milk powders. Lait 87:413-423.

Snoeren, T. H. M., J. A. Brinkhuis, A. J. Damman, and H. J. Klok. 1984. Viscosity and age-thickening of skim milk concentrates. Neth. Milk Dairy J. 38:43-53.

Sun, Y., J. Chen, S. Zhang, H. Li, J. Lu, L. Liu, H. Uluko, Y. Su, W. Cui, W. Ge, and J. Lv. 2014. Effect of power ultrasound pre-treatment on the physical and functional properties of reconstituted milk protein concentrate. J. Food Eng. 124:11-18.

Vos, B., S. V. Crowley, J. O’Sullivan, R. Evans-Hurson, S. McSweeney, J. Kruse, A. M. Rizwan, D. Fitzpatrick, and J. A. O'Mahony. 2016. New insights into the mechanism of rehydration of milk protein concentrate powders determined by Broadband Acoustic Resonance Dissolution Spectroscopy (BARDS). Food Hydrocoll. 61:933-945.

Walstra, P., J. Wouters, and T. Geurts. 2006. Dairy Science and Technology. 2nd ed. Food Science and Technology. CRC Press, Boca Raton, FL.

Wu, W. D., W. Liu, T. Gengenbach, M. W. Woo, C. Selomulya, X. D. Chen, and M. Weeks. 2014. Towards spray drying of high solids dairy liquid: Effects of feed solid content on particle structure and functionality. J. Food Eng. 123:130-135. 